\title{
Debtor's Accountability in the Composition of Liability for Breach of Contract
}

\author{
Yanfei Zhang* \\ School of International Law, Shanghai University of Political Science and Law, Shanghai, 201701, China \\ *Corresponding Author's Email: 1125071457@qq.com
}

\begin{abstract}
The matter of principle of liability attribution of liability for breach of contract has not been completely settled by the enactment of the Civil Code. An analysis of the relevant CISG rules shows that the so-called strict liability in Chinese law is a misinterpretation of Article 79 of the CISG. Comparative law has either taken debtor's accountability as the composition element of liability for breach of contract or considered debtor's accountability in the interpretation of contractual obligations. For Chinese law, an ideal solution would be to interpret Article 593 of the Civil Code in a purposive and restrictive manner to achieve a similar effect.
\end{abstract}

Keywords: The liability for breach of contract, principle of imputation, Article 79 of CISG, Third Party Causes

\section{INTRODUCTION}

As the generalization of the new Chinese civil legislation, the official enactment of the Civil Code marks the basic completion of the core task of Chinese civil legislation. However, although the compilation of the Civil Code has centralized the intellectual strength of the legislature, judiciary, administrative organs and academic field, it still leaves a number of fundamental matters unsettled. One of the most controversial matters in theory and practice is whether the composition of liability for breach of contract requires the debtor to be accountable. Scholars held different opinions on this matter as early as the formulation of the Contract Law, and after the enactment of the Contract Law, the academic field was divided on whether liability for breach of contract should be strict or fault-based.

The argument for strict liability for breach of contract under the Contract Law is that, first, in terms of legislation, legislation prior to the Contract Law (such as the General Principles of the Civil Law) defined liability for breach of contract as strict liability, and the strict liability was also adopted by model laws such as the Principles of International Commercial Contracts and the Principles of European Contract Law, which reflects a common trend in the development of contract law; second, in terms of the legitimacy of the rule itself, strict liability has the advantage of facilitating adjudication and enhancing the responsibility and legal awareness of the parties; finally, the contract is binding by the agreement of the parties, and the breach of agreement is sufficient in itself to hold the other party liable for breach of contract without requiring other reasons [1]. However, the objections argue the General Principles of the Civil Law have not characterize liability for breach of contract as strict liability. Article 106 (1) of the General Principles of the Civil Law stipulates the liability for breach of contract and the non-performance of other debts, while paragraph 3 stipulates the no-fault liability. From the systematic interpretation, the two are not stipulated together and it is not possible to conclude that the liability for breach of contract is strict liability. Moreover, when interpreting the relevant rules, Professor Tong Rou and other experts who participated in the legislation all agreed that the principle of liability attribution for breach of contract is fault liability. Second, it is too early to say that strict liability is the trend in the development of contract law. Most of the aforementioned model laws are applicable to the international sale of goods, which has a strong commercial normative attributes, while the civil codes of Germany, Netherlands and other countries adopt fault liability for breach of contract. Finally, the implementation of strict liability is not necessarily conducive to litigation economy, and it is equally controversial to treat the source of liability for breach of contract as simply a breach of the parties' agreement [2].

Although there has been controversy in the theoretical field on this matter, it is easy to see from the 
meaning of the provisions of the law, combined with the meaning of Article 577 and Article 593 of the Civil Code, the current Chinese law is still based on strict liability as the principle of of liability attribution for breach of contract. This is reflected in the fact that Article 577 does not require the debtor to be at fault when there is liability for breach of contract, and also in the fact that Article 593 does not affect the liability for breach of contract if a third-party reasons the breach. However, is such a rigorous liability rule really justified in terms of value judgements? Here it may be useful to illustrate by an example: $\mathrm{A}$ and $\mathrm{B}$ enter into a sales contract where it is agreed that A will deliver the goods to B's warehouse. On the way to deliver the goods to B's warehouse, A encounters a robber and the goods are robbed. A similar example would be if A assigns his own employee $\mathrm{C}$ to deliver the goods and $\mathrm{C}$ is involved in a car accident on the way to deliver the goods due to drunk driving, resulting in the goods being destroyed and lost. According to Article 593 of the Civil Code, in both of the aforementioned cases, A is liable to B for breach of contract due to a third party. The problem is that, in contrast to a breach of contract caused by the fault of the employee, it seems that the situation of robbery by robbers in the first case should not lead to liability for breach of contract on the part of Party A. However, since Article 593 of the Civil Code does not define the term "third party" in any way, the result in both cases is that A is liable for breach of contract. Such an opinion unduly expands the scope of risk borne by the debtor and is hardly reasonable in terms of value judgement. Therefore, this paper will discuss whether the accountability of the debtor is required for the composition of liability for breach of contract from the perspective of a breach caused by a third party.

\section{2. "RADICAL REFORM" OF STRICT LIABILITY}

Before analysing whether the composition of liability for breach of contract should require the accountability of the debtor, it is first necessary to clarify where the current rules of Chinese law come from. The rules on liability for breach of contract in the Civil Code are basically copied from the Contract Law, and according to scholars involved in the legislation of the Contract Law, the adoption of strict liability in the Contract Law is mainly based on the experience of the United Nations Convention on Contracts for the International Sale of Goods (CISG), which establishes principles such as autonomy of private law, principle of good faith and encouragement of contract formation that are in line with the needs of the market economy and represent the the future development direction of contract law [3].

Specifically, CISG does recognize the so-called strict liability, but at the same time, it provides an exemption from liability for breach of contract in Article 79, which is intended to protect the defaulting party from liability for risks beyond its control or avoidance and is a necessary limitation to the strict liability system. Under Article 79 (1), the debtor will not be liable for breach of contract when three conditions are met simultaneously: (1) The default must be due to an impediment beyond the control. (a) Generally, the range of impediments within the debtor's control is wide, but such as natural disasters, war, terrorist attacks, etc. are generally considered to be impediments beyond control; (2) The impediment is not reasonably foreseeable at the time the parties enter into the contract, of course, it does not mean that the clause can only apply to impediments arising after the contract has been entered into; the impediment may also have existed at the time of the conclusion of the contract and is simply unforeseeable by the debtor; (3) The debtor cannot be expected to overcome the impediment or its consequences. Generally, the debtor can only be relieved of liability for breach of contract if overcoming the impediment would require extraordinary expense and effort [4]. On this basis, the aforementioned case of robbery of goods by robbers satisfies the three requirements of Article 79 (1) of CISG. First, the accident is beyond the control of the debtor. A can't control over the robber's actions, since the robbery is based solely on the robber's consciousness. Second, the impediment to performance presented by the robber could not reasonably be foreseen; contemporary society is peaceful and the robbery is rare, so robbery is not expected by the debtor. Finally, the debtor cannot overcome its impediments or its consequences. Robberies are violent in nature and few debtors can overcome robberies by robbers and protect their goods. Therefore, the debtor is exempt from liability for breach of contract under Article 79 (1) of CISG.

In addition to Article 79 (1) of CISG, Article 79 (2) of CISG also stipulates an exemption from liability for breach of contract, according to which if the debtor's non-performance is due to the non-performance of a third party employed to perform all or part of the contract, the debtor is only exempt from liability if he is exempt under the previous paragraph and the provisions of that paragraph. If it applies to the person employed, that person shall also be exempt from liability. However, it should be noted that the scope of "third party" under Article 79 (2) of CISG is limited and that the "third party" in this paragraph must be the third party employed by the debtor to perform all or part of the contract. This is different from the scope of third party set out in Article 593 of the Civil Code, which does not restrict the scope of third party in any way, and anyone other than the parties to the contract is a third party for the purposes of this article. Therefore, in the case of the robber mentioned above, there is no matter of applying Article 79 (2) of CISG to determine whether the debtor is exempt from liability because there is no relationship of employment for the performance of the contract. 
However, in the case of the employee's drunk driving, Article 79 (2) of CISG applies.

According to the prevailing view, Article 79 (2) of CISG applies only to persons independent of the debtor [5]. It follows that the debtor's liability for defaults arising from the acts of its employees or from persons or units within its business organization is not subject to paragraph 2. This is because the debtor must assume the risks arising from its business organization. In conjunction with the definition of "scope of control" in Article 79 (1) above, the business organization should be included in the scope of control. Therefore, if the debtor's performance is impeded by the negligence of the employees, for example, the debtor himself should be held liable. However, it is worth mentioning that if the conduct of its employees is an impediment that could not be foreseen, avoided or overcome, such as a general strike, this certainly complies with the provisions of Article 79 (1), and exempts the debtor from liability. Therefore, in the above-mentioned case of the employee's drunk driving, the debtor should be held liable for breach of contract according to Article 79 (1) of CISG, which may appear to be the same conclusion as the Civil Code, but the principle is still different. Article 593 of the Civil Code treats the employee as a third party and the debtor is liable for breach of contract caused by all third parties. However, in CISG, the employee is not a third party within the meaning of Article 79 (2) and the liability of the debtor for breach of contract is not to be judged on the basis of paragraph 2, that is, a provision specifically designed for third parties, but on the basis of paragraph 1, "impediments beyond the control of the debtor".

It can be seen that the scope of "third party" in the CISG is smaller than that stipulated in the Civil Code. The CISG is more rationalized than the Civil Code, which classifies all persons other than the parties as third parties, and excludes from the scope of third parties only those third parties employed by the debtor to perform all or part of the contract, such as employees of the business organization, for the purposes of Article 79 (2). The inspiration from this is that although the rules of liability for breach of contract in Chinese law claim to be derived from CISG, there is actually a misinterpretation of the relevant CSIG rules. Since the claim that strict liability is derived from CISG cannot be justified, it is only natural that the CSIG rules should not be used as a basis for justifying strict liability. It is necessary to consider how the matter of the accountability of the debtor should be dealt with in relation to the composition of liability for breach of contract.

\section{DEBTOR'S ACCOUNTABILITY FROM THE COMPARATIVE LAW PERSPECTIVE}

Based on the above analysis of third-party reasons of default it is clear that solution to the principle of liability attribution for breach of contract is problematic in China. Before identifying possible options for improvement, it is useful to observe the attitude in comparative law towards the accountability of the debtor.

\subsection{German Law}

The basic position taken by German law on the liability for breach of contract is fault liability. In other words, in the field of contractual liability, the liability in principle depends on the existence of fault [6].

First, the debtor is normally liable for intention and negligence under Article 276 of the German Civil Code. Intention means that the debtor knows and wishes the objective element to be fulfilled; negligence means that the debtor could know and could avoid the fulfilment of the objective element and, according to Article 276 of the German Civil Code, negligence is to be judged by taking into account whether the debtor complied with the care necessary to avoid the breach of the obligation in the context of the relationship. The standard to be noted is the competence of the ordinary members of the circle of intercourse involved. Such standard should not be based on objective standard, and in individual cases, it is important to distinguish between different circles and age groups [7].

Second, in terms of the liability assumed for the auxiliary performer and the legal representative. The debtor is liable for the fault and all actions of the auxiliary performer and the legal representative. In this context, the auxiliary performer is a person who acts as an auxiliary to the debtor within the scope of the debtor's obligations, including non-independent auxiliaries as well as independent operators employed. The legal representative is any person who, by virtue of the law, is able to perform legal acts that have effects on others. The elements of the debtor's liability for the fault of the auxiliary performer and the legal representative include: 1. The existence of debt relationship; 2. The action performed by the auxiliary performer or the legal representative is an action in fulfilment of the debtor's debt; 3. The debtor should be liable for the fault of the auxiliary performer or the legal representative to the same extent as his own fault. The determination of the standard for fault should be based on the standard necessary for professionals to carry out their work [8].

However, German law does not adopt fault liability for all contractual liability and adopts a no-fault approach to liability attribution where the parties express liability for the outcome of the payment.

\subsection{Japanese Law}


In terms of liability attribution, the early years of Japanese scholarship used the German and French theories, but in recent years, new theories have addressed the matter of liability attribution through the interpretation of the content of the contract. For example, Hiroki Morita argues that in the case of a debt of result, the debtor's obligation is to achieve a particular result and the principle of liability attribution is that if the particular result is not achieved, there is a breach of contract, whereas in the case of a debt of means, the debtor's obligation is to diligently perform a particular act and the principle of liability attribution is that if the particular act is not diligently performed, there is a breach of contract. The common point in both cases is the failure to perform its contractual obligations, thus, the matter of the principle of liability attribution is transformed into a matter of non-performance of the debt. The Basic Guidelines for the Correction of the Law of Obligation in Japan stipulates that as long as the content of the debt is part of it and is not performed on time and properly, then the debtor is liable for breach of contract. It can be seen from this that Japanese scholarship has placed the issue of liability for breach of contract on the interpretation of the content of the contract [9]. In the absence of an agreement in the contract, the Japanese scholarship has adopted the theory of "interpretation of incomplete contracts" to expand the content of the contract by simulating the true intention of the parties in the case of "matters not agreed upon", and then In this way, the debtor's liability for breach of contract is settled.

\section{THE COMPOSITION OF LIABILITY FOR BREACH OF CONTRACT UNDER CHINESE LAW}

Each country has different rules on the matter of the accountability of the debtor, but the effect in practice is similar. Many matters can be settled in the same reasonable way using different principles of liability attribution. On the whole, most civil law countries have adopted fault liability as the principle of liability attribution for breach of contract. In terms of Chinese law, considering that the Civil Code has just been issued, the relevant matters should be settled through legal interpretation as far as possible. Specifically, a purposive and restrictive interpretation of the third-party reason in Article 593 of the Civil Code can be considered.

It is clear from the previous analysis that the third party stipulated in Article 593 of the Civil Code is everyone other than the parties to the contract. But is it really the purpose of the legislation to include such a wide range of third-party reasons of failure to perform within the scope of the debtor's liability? Certainly not, since China has entered into the market economy, transactions have been encouraged in order to promote economic development, but if the debtor may be liable for such a heavy breach of contract from the start, this is bound to make the debtor fearful of the transaction and afraid of being liable for a serious breach of contract due to a third party over whom he has no control. Furthermore, the purpose of Article 593 is, according to various doctrines, to emphasize the principle of relativity of contract. The validity of the contract exists only between the parties to the contract, if a party breaches the contract because of a third party, it would be contrary to the principle of contractual relativity if the court imposes liability on a third party outside the contract. However, the purpose of legislation never excluded the possibility of a direct claim by the non-breaching party against the third party, since the legislator did not make Article 593 "only one party may be liable to the non-breaching party". Thus, the purpose of legislation is only to emphasise the principle of contractual relativity, but not to impute liability to the debtor for any breach of contract caused by a third party [10]. So, we can and should limit for third-party reasons, but how is it more appropriate to limit?

Before discussing the issue of limitation, it may be that the following issue also needs to be clarified for better understanding. For third-party reason defaults in Article 593. It is important to emphasise that if the debtor is bound to be in default regardless of the third-party reason, such third-party reason does not fall within the scope of third-party reason in Article 593. In this regard, if Article 593 is to be invoked to impose liability, a judgment should first be made as to the fact of the breach and, if there is a breach, whether it was caused by the presence of a third party. On this basis, the third-party reason to be discussed is the reason of the third party who substantially caused the failure to perform.

In interpreting the "liability of the debtor to the third party" of the German Civil Code, some scholars have applied the principle of "allocation of risk", arguing that any debtor should be liable to his own creditors for the scope of his own affairs and risks, and that the activities of his own auxiliaries also fall within this scope. The activities of one's auxiliaries also fall within this scope [11].

Here, we can perhaps refer to the principle of "allocation of risk" for an explanation of the scope of third-party reasons. The debtor is liable to the fact of default within its own risk. The core matter is whether the result of a breach caused by the conduct of a third party should be attributed to the debtor's risk. Not all defaults caused by the actions of third parties can be classified as being within the debtor's risk. Only defaults caused by third-party reasons that the debtor could foresee, or could avoid or take measures to overcome the consequences, can be classified as being within the debtor's risk. It is unreasonable to classify as a debtor's risk the result of a default brought about by the third-party reason that the debtor could not foresee, avoid or overcome from the start, because its appearance, occurrence and resulting 
consequences are beyond the debtor's control and for which the debtor is not at all at fault. From an objective perspectives, it would indeed be unreasonable for a kind debtor to take such a risk. Therefore, I believe that third-party reasons should be limited to those that are attributable to the debtor's risk and are third-party reasons that the debtor could foresee or could avoid or whose consequences could be overcome by measures.

\section{CONCLUSION}

In terms of the rules on liability for breach of contract, Chinese law adopts the position of strict liability. Many scholars believe that Chinese law has adopted strict liability because it draws on the provisions of CISG, but it is clear from both the exclusion of liability and the liability for breach of contract due to third-party reasons that the provisions of Chinese law and CISG are not consistent. Compared to the practice in other countries, the principle of liability attribution in Chinese law is too rigorous, resulting in an unreasonable range of risks for the debtor. In terms of interpretive theory, the liability attribution principle can be rationalized by a purposive and restrictive interpretation of the third party in Article 593.

\section{REFERENCES}

[1] Liang Huixing: From Fault Liability to Strict Liability - on Article 76(1) of the Draft for Comments of Contract Law, Civil and Commercial Law Review, (Volume 8) Law Press-China 1997, p1-7.

[2] Cui Jianyuan: Strict Liability? Fault Liability? - on the Legislation of the Principle of Liability Attribution of Chinese Contract Law, Civil and Commercial Law Review, (Volume 11), Law Press. China 1999, p190-197 .

[3] Wang Liming: Formulation and Perfection of the United Nations Convention on Contracts for the International Sale of Goods and Chinese Contract Law, Global Law Review, 2013, Issue 5, p119-131.

[4] Peter Huber, Alastair Mullis,The CISG_A New Textbook for Students and Practitioners (2007), p259-262.

[5] Peter Huber, Alastair Mullis,The CISG_ A New Textbook for Students and Practitioners (2007), p263.

[6] Xie Gen: Reconstruction of the Theory of Contractual Binding in China, Chinese Journal of Law, 2011, Issue 2.

[7] Looschelders: Schuldrecht Allgemeiner Teilll (7. Auflage), translated by Shen Xiaojun and Zhang
Jinhai, China Renmin University Press, 2014, p183-185.

[8] Looschelders: Schuldrecht Allgemeiner Teilll (7. Auflage), translated by Shen Xiaojun and Zhang Jinhai, China Renmin University Press, p192-195.

[9] Ke Weicai: Opposition and Integration of the Principle of Liability Attribution of Debt Non-performance, ECUPL Journal, 2017, Issue 1.

[10] Zhou Jianghong: Understanding and Application of Article 121 of Contract Law, Tsinghua University Law Journal, 2012, Issue 5.

[11] Du Jinglin, Lu Chen: Commentary on the German Civil Code: General Principles x Obligation Law x Property Right, Law Press·China, 2011, p110. 